\title{
Genetic Variants in Group-Specific Component (GC) Gene Are Associated with Breast Cancer Risk among Chinese Women
}

\author{
Fuxing Chen, ${ }^{1}$ Zheng Zhu $\mathbb{C D}^{2}{ }^{2}$ Fränzel J. B. van Duijnhoven ${ }^{(D)},{ }^{3}$ Meihua Dong, ${ }^{4}$ Yun Qian, ${ }^{4}$ \\ Hao Yu, ${ }^{2}$ Jie Yang, ${ }^{2}$ Lan Cui, ${ }^{2}$ Renqiang Han, ${ }^{2}$ Jian Su, ${ }^{2}$ Wencong Du, ${ }^{2}$ Jinyi Zhou, ${ }^{2}$ \\ and Ming $\mathrm{Wu} \mathbb{i D}^{1,2}$ \\ ${ }^{1}$ Department of Epidemiology and Biostatistics, School of Public Health, Nanjing Medical University, Nanjing 211166, China \\ ${ }^{2}$ Department of Chronic Disease Control, Jiangsu Provincial Center for Disease Control and Prevention, Nanjing 210009, China \\ ${ }^{3}$ Division of Human Nutrition and Health, Wageningen University \& Research, Wageningen, Netherlands \\ ${ }^{4}$ Department of Chronic Disease Control, Wuxi Center for Disease Control and Prevention, Wuxi 214023, China
}

Correspondence should be addressed to Ming Wu; jswuming@vip.sina.com

Fuxing Chen and Zheng Zhu contributed equally to this work.

Received 7 May 2019; Revised 16 September 2019; Accepted 12 October 2019; Published 15 November 2019

Academic Editor: Klaus Wimmers

Copyright (c) 2019 Fuxing Chen et al. This is an open access article distributed under the Creative Commons Attribution License, which permits unrestricted use, distribution, and reproduction in any medium, provided the original work is properly cited.

The group-specific component (GC) gene, one of the vitamin D pathway genes, seems to play an important role in cancer development. A population-based breast cancer study including 818 cases and 935 controls in a Chinese population was carried out to evaluate the potential associations of four polymorphisms (rs16847024, rs17467825, rs2298850, and rs3755967) in the GC gene with risk of breast cancer. We detected three SNPs with statistically significant effects on breast cancer development after adjusting for age, menopausal status, body mass index (BMI), family history of breast cancer, income, waist circumference, and education ( $\mathrm{rs} 17467825$ : adjusted $\mathrm{OR}=0.80,95 \% \mathrm{CI}=0.65-0.99 ; \mathrm{rs} 2298850$ : adjusted $\mathrm{OR}=0.80,95 \% \mathrm{CI}=0.65-0.98$; $\mathrm{rs} 3755967$ : adjusted $\mathrm{OR}=0.80,95 \% \mathrm{CI}=0.65-0.98)$. Stratified analysis found that when an individual had a waist circumference $<80 \mathrm{~cm}$, rs 17467825, rs2298850, and rs3755967 could markedly reduce the risk of breast cancer. Significant interactions between polymorphisms of rs2298850 and rs3755967 and waist circumference were also observed for breast cancer risk. Combined analysis revealed a significant association among the allele numbers of protective effects with decreased breast cancer risk $\left(P_{\text {trend }}=0.043\right)$. These results indicated that, in the GC gene, genetic mutations might be related to breast cancer susceptibility in Chinese women.

\section{Introduction}

Breast cancer is the common therioma in women around the world, with an estimation of 2.1 million new cases and 626,679 deaths [1]. Similar with other countries, breast cancer has become the most frequent carcinoma among the Chinese women. In China, patients with breast cancer make up $11.2 \%$ of newly diagnostic cases and $9.2 \%$ of breast cancer-related deaths worldwide [2]. As in most other diseases, besides behavioral factors and environmental exposures, genetic variations also make an essential contribution to breast cancer occurrence as well as risk prediction.

A growing number of epidemiological researches have reported that vitamin $\mathrm{D}$ could lower the breast cancer risk in humans [3-5]. Vitamin D, as a prohormone, can be changed in the liver into $25(\mathrm{OH}) \mathrm{D}$ which can be further hydroxylated to $1,25(\mathrm{OH})_{2} \mathrm{D}$ by $1 \alpha$-hydroxylase in the kidney [6]. Vitamin D binding protein (DBP), a pivotal protein, is encoded by the group-specific component gene (GC gene), which is $42.5 \mathrm{~kb}$ long and located on chromosome 4 [7]. The functions of DBP are to bind 25(OH)D to prolong its half-life in circulation, as well as transport $25(\mathrm{OH}) \mathrm{D}$ to different sites to facilitate vitamin $\mathrm{D}$ physiological roles, such as cell proliferation, apoptosis, and differentiation [8]. DBP is highly polymorphic serum protein, characterized by three common alleles (GC1F, GC1S, and GC2) and more than 120 identified rare variants [9]. GC1F, GC1S, and GC2 from rs7041 and rs4588 combination differ in binding affinities with 25(OH)D and therefore result in alteration of serum $25(\mathrm{OH}) \mathrm{D}$ 
concentration [10], which may correlate with risk of diseases, like diabetes, melanoma, and breast cancer [11-13].

Previous studies on the GC gene polymorphism mainly focused on rs7041 and rs4588 and have demonstrated their associations with the risk of different cancers [14, 15]. Elkum [16] et al. revealed that homozygous variants of rs17467825, rs2298850, and rs3755967 were associated with lower levels of serum 25(OH)D among Arabs and South Asians, whereas decreased serum $25(\mathrm{OH}) \mathrm{D}$ levels have been shown to be tightly associated with increased risk of several malignant tumors [17, 18]. In addition, Pibiri et al. found that rs16847024 could affect individual susceptibility to colorectal cancer [19]. Currently, the associations between these genetic variants (rs16847024, rs17467825, rs2298850, and rs3755967) and breast cancer risk remain absent due to investigation; based on the previous findings, we reasonably hypothesized that they might contribute to breast carcinogenesis and thus explore the mutual relations among the Chinese women in this study.

\section{Materials and Methods}

2.1. Statement of Ethics. The Ethics Committee of Jiangsu Provincial Center for Disease Control and Prevention approved this work. All study subjects were voluntary and have completed written informed consent.

2.2. Study Participants. The subjects including 1,410 cases and 1,072 cancer-free controls were recruited between 2013 and 2014 in the largest Wuxi Maternal and Child Health Hospital. All breast cancer cases were newly diagnosed. The exclusion criteria were as follows: (1) a metastatic carcinoma from other sites, (2) a recent history of severe acute diseases, and (3) failed to complete questionnaires. As a result, 818 cases were included. Controls resided in the same areas and were frequency matched with cases by age (within 5 years old); a total of 935 controls were finally included in the present analysis. Standard questionnaires were used to interview each participant to acquire information about demographic data, family history of breast cancer, reproductive and menstrual history, and relevant factors. Several anthropometric measurements, such as height, weight, and waist circumference, were collected during interview stages. Each participant provided approximately $5 \mathrm{ml}$ venous blood sample for subsequent laboratory measurements.

2.3. Genotyping. Total DNA was isolated from the blood sample with the use of QIAamp DNA Blood Mini Kit (QIAGEN, Germany) and stored in a $-80^{\circ} \mathrm{C}$ refrigerator. The Sequenom MassARRAY Platform was applied to perform genotyping without knowing the status of subjects. Around $5 \%$ of samples were randomly selected for quality control and regenotyped by this platform, and the two results were consistent. Haploview 4.2 was used to examine the linkage disequilibrium of four SNPs. The detailed information of four SNPs in the GC gene is displayed in Table S1.
2.4. Statistical Analysis. Differences between cases and controls in the demographic characteristics and selected variables were tested using student's $t$-test (for continuous variables) or Welch's $t$-test (for the situations of unequalled variances) and $\chi 2$ test (for categorical variables). Logistic regression was applied to evaluate the associations between four SNPs in GC gene and risk of breast cancer. Odds ratios (ORs) and 95\% confidence intervals (CIs) were presented with adjusting for age, menopausal status, body mass index (BMI), family history of breast cancer, income, waist circumference, and education. The effect heterogeneity between corresponding subgroups was measured by using the $\chi$ 2-based Q-test. Three additive interaction measures [20] were calculated by the epiR packages: (1) RERI: relative excess risk due to interaction; (2) AP: attributable proportion due to interaction; and (3) S: synergy index. 95\% CIs of RERI and AP across 0 as well as S across 1 indicate no additive interaction effect. The multiplicative interaction of gene environment was also analyzed using logistic regression by the function as described previously [21]:

$$
y=b_{0}+b_{1} \times g+b_{2} \times e+b_{3} \times(g \times e),
$$

in which $y$ is the case or control logit status, $g$ represents the $\mathrm{SNP}, e$ indicates the environment factor: waist circumference, $b_{0}$ is the constant, $b_{1}$ and $b_{2}$ are main effects for $g$ and $e$, respectively, and $b_{3}$ is the multiplicative interaction term. $P<0.05$ was as a significant level with two-sided among all statistical tests. Combined analysis was applicable to evaluate the cumulative effect of protective alleles from significant SNPs (rs17467825, rs2298850, and rs3755967). Statistical analyses were carried out using $R$ software (version: 3.5.0).

\section{Results}

3.1. Demographic Characteristics of Cases and Controls. The demographic characteristics of 818 cases and 935 controls are shown in Table 1. In short, significant differences were not found in age, age at menarche, age at first live birth, and age at menopause. Compared with cancer-free controls, cases were not inclined to higher education levels and household incomes but were prone to a positive family history of breast cancer. Different distributions of body mass index (BMI) and menopausal status were also observed. Of all subjects, 604 (73.84\%) cases and 549 (58.78\%) controls were postmenopausal, and 465 (57.48\%) cases and 449 (48.03\%) appeared to be overweight or obese.

3.2. Associations between Four SNPs of GC Gene and Breast Cancer Risk. Genotyping assays indicated that the controlgroup genotype frequencies of four SNPs were in HardyWeinberg equilibrium, and call rates of all individuals were above $95 \%$ for these four SNPs. The four SNPs genotypes among cases and controls as well as the correlations with risk of breast cancer are presented in Table 2. We carried out linkage disequilibrium analysis of four SNPs and found except for rs16847024, other three SNPs with $r^{2}>0.8$ (Figure S1). Compared with the AA genotype, logistic regression results showed that AG of rs17467825 was in association with a decreased breast cancer risk $(\mathrm{OR}=0.77,95 \%$ 
TABLE 1: Characteristics of cases and controls.

\begin{tabular}{|c|c|c|c|}
\hline Variables & $\begin{array}{c}\text { Cases }(n=818) \\
N(\%)\end{array}$ & $\begin{array}{c}\text { Controls }(n=935) \\
N(\%)\end{array}$ & $P$ value \\
\hline $\begin{array}{l}\text { Age }(\text { mean } \pm S D \text {, year }) \\
\quad<53 \\
\geq 53\end{array}$ & $\begin{array}{c}54.78 \pm 11.10 \\
393(48.04) \\
425(51.96) \\
\end{array}$ & $\begin{array}{c}54.27 \pm 11.30 \\
458(48.98) \\
477(51.02) \\
\end{array}$ & $\begin{array}{c}0.337 \\
0.730^{\mathrm{b}}\end{array}$ \\
\hline $\begin{array}{l}\text { Age at menarche (mean } \pm \mathrm{SD} \text {, year) } \\
\text { Age at first live birth (mean } \pm \mathrm{SD} \text {, year) } \\
\text { Chest circumference (mean } \pm \mathrm{SD}, \mathrm{cm}) \\
\text { Age at menopause (mean } \pm \mathrm{SD} \text {, year) } \\
\text { Waist circumference (mean } \pm \mathrm{SD}, \mathrm{cm})\end{array}$ & $\begin{array}{l}15.52 \pm 2.55 \\
24.60 \pm 2.70 \\
90.40 \pm 8.69 \\
49.18 \pm 4.87 \\
87.31 \pm 10.98 \\
\end{array}$ & $\begin{array}{l}15.48 \pm 2.73 \\
24.58 \pm 2.48 \\
90.70 \pm 7.90 \\
49.29 \pm 6.04 \\
83.07 \pm 9.84 \\
\end{array}$ & $\begin{array}{c}0.762^{\mathrm{a}} \\
0.875^{\mathrm{a}} \\
0.451^{\mathrm{a}} \\
0.727^{\mathrm{a}} \\
<0.001^{\mathrm{a}} \\
\end{array}$ \\
\hline $\begin{array}{l}\text { Menopausal status at baseline } \\
\text { Premenopausal } \\
\text { Postmenopausal }\end{array}$ & $\begin{array}{l}214(26.16) \\
604(73.84) \\
\end{array}$ & $\begin{array}{l}385(41.22) \\
549(58.78) \\
\end{array}$ & $<0.001^{b}$ \\
\hline $\begin{array}{l}\text { Body mass index }\left(\text { mean } \pm \mathrm{SD}, \mathrm{kg} / \mathrm{m}^{2}\right) \\
\quad<18.5 \\
18.5-23.9 \\
24.0-27.9 \\
\geq 28.0\end{array}$ & $\begin{array}{c}24.93 \pm 3.54 \\
19(2.35) \\
325(40.17) \\
330(40.79) \\
135(16.69) \\
\end{array}$ & $\begin{array}{c}24.14 \pm 3.16 \\
15(1.60) \\
471(50.37) \\
339(36.26) \\
110(11.77) \\
\end{array}$ & $\begin{array}{l}<0.001^{\mathrm{a}} \\
<0.001^{\mathrm{b}}\end{array}$ \\
\hline $\begin{array}{l}\text { Education } \\
\text { Primary school } \\
\text { Junior middle school } \\
\text { Senior middle school } \\
\text { University and above } \\
\end{array}$ & $\begin{aligned} & 256(31.33) \\
& 348(42.60) \\
& 148(18.12) \\
& 65(7.96) \\
&\end{aligned}$ & $\begin{array}{l}228(24.44) \\
341(36.55) \\
225(24.12) \\
139(14.90)\end{array}$ & $<0.001^{b}$ \\
\hline $\begin{array}{l}\text { Income (yuan) } \\
\quad<30000 \\
30000-49999 \\
50000-100000 \\
\geq 100000\end{array}$ & $\begin{array}{l}216(26.54) \\
163(20.02) \\
265(32.56) \\
170(20.88)\end{array}$ & $\begin{array}{l}149(15.94) \\
121(12.94) \\
317(33.90) \\
348(37.22) \\
\end{array}$ & $<0.001^{\mathrm{b}}$ \\
\hline $\begin{array}{l}\text { Oral contraceptive use } \\
\text { No } \\
\text { Yes }\end{array}$ & $\begin{array}{l}652(80.10) \\
162(19.90) \\
\end{array}$ & $\begin{array}{l}760(82.16) \\
165(17.84) \\
\end{array}$ & $0.299^{\mathrm{b}}$ \\
\hline $\begin{array}{l}\text { Family history of breast cancer } \\
\text { No } \\
\text { Yes }\end{array}$ & $\begin{array}{c}711(88.76) \\
90(11.24)\end{array}$ & $\begin{array}{r}873(94.38) \\
52(5.62)\end{array}$ & $<0.001^{\mathrm{b}}$ \\
\hline
\end{tabular}

${ }^{\mathrm{a}}$ Welch's $t$-test was applied for the unequal variances. ${ }^{\mathrm{b}}$ Two-sided chi-square test.

$\mathrm{CI}=0.62-0.96)$. For rs2298850, individuals carrying GC genotype could lower the risk of breast cancer compared with the $\mathrm{GG}$ genotype $(\mathrm{OR}=0.78,95 \% \mathrm{CI}=0.63-0.97)$. Also, the CT genotype of rs3755967 could reduce risk of breast cancer with an OR of $0.77(95 \% \mathrm{CI}=0.62-0.96)$. We also found three SNPs (rs17467825, rs2298850, and rs3755967) with significant association effects on breast cancer under a dominant model after adjusting for selected confounders (rs17467825: $\mathrm{OR}=0.80,95 \% \mathrm{CI}=0.65-0.99 ;$ rs2298850: $\mathrm{OR}=0.80,95 \% \mathrm{CI}=0.65-0.98 ; \mathrm{rs} 3755967: \mathrm{OR}=0.80,95 \%$ $\mathrm{CI}=0.65-0.98)$. However, we failed to find any association of rs16847024 genotypes with breast cancer risk.

3.3. Associations between Four SNPs and Breast Cancer Risk by Stratified Analyses. Further subgroup analyses stratified by age, menopausal status, family history, and waist circumference were conducted, and results are shown in Table 3. For rs17467825, rs2298850, and rs3755967, significant reduced risk of these three SNPs with breast cancer was observed among the subgroup of waist circumference $<80 \mathrm{~cm}$, the OR $(95 \% \mathrm{CI})=0.69(0.51-0.93), \mathrm{OR}(95 \% \mathrm{CI})=0.66(0.49-0.89)$, and OR $(95 \%$ CI $)=0.67(0.50-0.91)$, respectively. Significant heterogeneities were observed in the subgroup of waist circumference $(P=0.035$ for rs17467825, 0.019 for rs2298850, and 0.023 for rs3755967, respectively). Among the subgroups of age, menopause, and family history, there were no statistically significant associations observed.

3.4. Interactions of $r s 17467825$, rs2298850, and rs3755967 with Waist Circumference on Breast Cancer Risk. In effort to explore whether or not the identified mutations effects on risk of breast cancer could be modified by waist circumference, we evaluated the interactions of rs17467825, rs2298850, and rs3755967 genotypes and waist circumference. As shown in Table 4, we examined multiplicative interactions between rs2298850 and rs3755967 genotypes and waist circumference on risk of breast cancer ( $P$ for multiplicative interaction $=0.031$ and 0.039 , respectively). However, no interaction was detected between rs17467825 and waist circumference on risk of breast cancer ( $P$ for multiplicative interaction $=0.057$ ). For rs2298850, compared with the waist circumference $\geq 80 \mathrm{~cm}$ with the GG genotype, a significant decreased risk of breast cancer was observed for those with GC or CC genotypes with the waist 
TABLE 2: Summary of associations between genetic variants and breast cancer risk.

\begin{tabular}{|c|c|c|c|c|c|}
\hline Genotype & Cases & Controls & Crude OR (95\% CI) & Adjusted OR $(95 \% \mathrm{CI})^{\mathrm{b}}$ & $P^{\mathrm{b}}$ \\
\hline \multicolumn{6}{|l|}{$\mathrm{rs} 16847024(\mathrm{C}>\mathrm{T})^{\mathrm{a}}$} \\
\hline $\mathrm{CC}$ & 612 & 708 & 1.00 & 1.00 & \\
\hline $\mathrm{CT}$ & 175 & 203 & $1.00(0.79-1.26)$ & $0.93(0.73-1.19)$ & 0.556 \\
\hline TT & 13 & 14 & $0.99(0.46-2.16)$ & $0.97(0.43-2.22)$ & 0.946 \\
\hline $\mathrm{CT} / \mathrm{TT}$ & 188 & 217 & $1.00(0.80-1.25)$ & $0.93(0.73-1.18)$ & 0.562 \\
\hline Additive model & & & $1.00(0.81-1.22)$ & $0.94(0.76-1.17)$ & 0.594 \\
\hline \multicolumn{6}{|l|}{ rs17467825 (A > G) } \\
\hline $\mathrm{AA}$ & 377 & 402 & 1.00 & 1.00 & \\
\hline AG & 325 & 414 & $0.83(0.68-1.02)$ & $0.77(0.62-0.96)$ & 0.020 \\
\hline GG & 89 & 93 & $1.02(0.74-1.41)$ & $0.95(0.67-1.35)$ & 0.785 \\
\hline AG/GG & 414 & 507 & $0.87(0.72-1.05)$ & $0.80(0.65-0.99)$ & 0.039 \\
\hline Additive model & & & $0.95(0.82-1.09)$ & $0.90(0.77-1.05)$ & 0.181 \\
\hline \multicolumn{6}{|l|}{ rs2298850 (G>C) } \\
\hline GG & 367 & 393 & 1.00 & 1.00 & \\
\hline GC & 341 & 428 & $0.85(0.69-1.04)$ & $0.78(0.63-0.97)$ & 0.025 \\
\hline $\mathrm{CC}$ & 89 & 99 & $0.96(0.70-1.33)$ & $0.89(0.63-1.27)$ & 0.530 \\
\hline GC/CC & 430 & 527 & $0.87(0.72-1.05)$ & $0.80(0.65-0.98)$ & 0.035 \\
\hline Additive model & & & $0.93(0.81-1.08)$ & $0.89(0.76-1.03)$ & 0.123 \\
\hline \multicolumn{6}{|l|}{ rs3755967 $(\mathrm{C}>\mathrm{T})$} \\
\hline CC & 372 & 396 & 1.00 & 1.00 & \\
\hline $\mathrm{CT}$ & 332 & 420 & $0.84(0.68-1.02)$ & $0.77(0.62-0.96)$ & 0.021 \\
\hline $\mathrm{TT}$ & 90 & 97 & $0.99(0.72-1.36)$ & $0.92(0.65-1.30)$ & 0.627 \\
\hline $\mathrm{CT} / \mathrm{TT}$ & 422 & 517 & $0.86(0.71-1.05)$ & $0.80(0.65-0.98)$ & 0.035 \\
\hline Additive model & & & $0.94(0.81-1.08)$ & $0.89(0.76-1.04)$ & 0.143 \\
\hline
\end{tabular}

${ }^{a}$ Major allele $>$ minor allele. ${ }^{b}$ Derived from logistic regression with an adjustment for age, menopausal status, BMI, family history, income, waist circumference, and education. OR, odds ratio.

circumference $<80 \mathrm{~cm}$, whereas a nonsignificant increased breast cancer risk was observed for those with the CC genotype with the waist circumference $\geq 80 \mathrm{~cm}$. The additive interactions between waist circumferences and the SNPs (rs17467825, rs2298850, and rs3755967) were also examined. However, significant additive interactions were not measured between these three SNPs and waist circumferences (Table S2).

3.5. Combined Effects on Breast Cancer Risk. Previous results were mainly focused on the investigation of the association of single SNP with breast cancer risk. Combined analysis was also performed to estimate accumulative effects of these polymorphisms. In Table 5, we identified allele-dosage relation between allele numbers of the protective effect and risk of breast cancer $\left(P_{\text {trend }}=0.043\right)$. Compared with subjects carrying " 0 " protective alleles, individuals with " $1-2$ " alleles of protective effects could possess a nonsignificant $10 \% \quad(\mathrm{OR}=0.90,95 \% \mathrm{CI}: 0.37-2.20, P=0.816)$ reduced cancer risk, whereas " $3-6$ " protective alleles could decrease a $19 \%(\mathrm{OR}=0.81,95 \% \mathrm{CI}: 0.66-0.99, P=0.044)$ breast cancer risk.

\section{Discussion}

In this work, we estimated the correlations between four genetic variants in GC gene (rs16847024, rs17467825, rs2298850, and rs3755967) and risk of breast cancer in Chinese population and found that heterozygotes of rs17467825, rs2298850, and rs3755967 but not rs16847024 were in significant relation to the breast cancer risk. Also, in the dominant model, three SNPs (rs17467825, rs2298850, and rs3755967) were observed with an approximately $20 \%$ decreased breast cancer risk in our study population. Combined analysis also implied that subjects carrying more alleles of the protective effect could decrease the breast carcinogenesis risk.

Epidemiological studies supported that 25(OH)D was related with breast cancer risk $[13,22]$. The active vitamin $\mathrm{D}$, $1,25(\mathrm{OH})_{2} \mathrm{D}$, has an effect not only on cell proliferation and apoptosis but also on the estrogen signal pathway [23]. When the circulating $25(\mathrm{OH}) \mathrm{D}$ integrated to DBP, the complex, 25(OH)D-DBP, could be internalized in mammary cells by megalin-mediated endocytosis, and the complex internalization had a connection with activation of the vitamin D receptor pathway [24]. In addition, when the complex was internalized, $25(\mathrm{OH}) \mathrm{D}$ was released from DBP. In the mammary gland, low concentrations of $25(\mathrm{OH}) \mathrm{D}$ might weaken enzyme activity and production of $1,25(\mathrm{OH})_{2} \mathrm{D}$, which regulated cell proliferation and apoptosis $[25,26]$. Furthermore, one study has demonstrated that $25(\mathrm{OH}) \mathrm{D}$ concentrations played a role in growth inhibition of mammary cells [27].

A breast cancer research in Shanghai showed that about $23 \%$ of women involved in study were vitamin D deficiency and $48.4 \%$ were vitamin D insufficiency [28]. One study conducted among Chinese pregnant women found that 8 SNPs, including rs17467825, rs2298850, and rs3755967, were in associations with concentrations of $25(\mathrm{OH}) \mathrm{D}$ [29]. A case-control study found that women with $25(\mathrm{OH})$ $\mathrm{D}<20 \mathrm{ng} / \mathrm{ml}$ and calcium levels $<10.5 \mathrm{mg} / \mathrm{dl}$ had higher risk 
TABLE 3: Stratified analyses of association between 4 SNPs and breast cancer risk.

\begin{tabular}{|c|c|c|c|c|c|c|c|c|}
\hline & \multicolumn{2}{|c|}{ Age (years) } & \multicolumn{2}{|c|}{ Menopausal status } & \multicolumn{2}{|c|}{ Family history } & \multicolumn{2}{|c|}{ Waist circumference $(\mathrm{cm})$} \\
\hline & $<53$ & $\geq 53$ & Premenopause & Postmenopause & No & Yes & $<80$ & $\geq 80$ \\
\hline \multicolumn{9}{|l|}{$\begin{array}{l}\mathrm{rs} 16847024 \\
(\mathrm{C}>\mathrm{T})\end{array}$} \\
\hline OR $(95 \% C I)^{\mathrm{a}}$ & $\begin{array}{c}1.00 \\
(0.72-1.38)\end{array}$ & $\begin{array}{c}0.95 \\
(0.70-1.27)\end{array}$ & $\begin{array}{c}1.01 \\
(0.69-1.48)\end{array}$ & $\begin{array}{c}0.92 \\
(0.70-1.20)\end{array}$ & $\begin{array}{c}0.94 \\
(0.75-1.18)\end{array}$ & $\begin{array}{c}1.18 \\
(0.50-2.77)\end{array}$ & $\begin{array}{c}1.04 \\
(0.68-1.58)\end{array}$ & $\begin{array}{c}0.95 \\
(0.73-1.22)\end{array}$ \\
\hline$P$ value $^{\mathrm{a}}$ & 0.983 & 0.720 & 0.957 & 0.517 & 0.588 & 0.702 & 0.863 & 0.670 \\
\hline $\begin{array}{l}P \text { for } \\
\text { heterogeneity }\end{array}$ & & 0.832 & & 0.226 & & 0.613 & & 0.719 \\
\hline \multicolumn{9}{|l|}{$\begin{array}{l}\text { rs17467825 } \\
(A>G)\end{array}$} \\
\hline OR $(95 \% C I)^{\mathrm{a}}$ & $\begin{array}{c}0.84 \\
(0.67-1.06)\end{array}$ & $\begin{array}{c}0.97 \\
(0.78-1.20)\end{array}$ & $\begin{array}{c}0.86(0.65-1- \\
1.14)\end{array}$ & $0.95(0.79-1.14)$ & $\begin{array}{c}0.87 \\
(0.74-1.02)\end{array}$ & $\begin{array}{c}1.23 \\
(0.66-2.28)\end{array}$ & $\begin{array}{c}0.69 \\
(0.51-0.93)\end{array}$ & $\begin{array}{c}1.01 \\
(0.84-1.21)\end{array}$ \\
\hline$P$ value $^{\mathrm{a}}$ & 0.135 & 0.775 & 0.289 & 0.565 & 0.09 & 0.512 & 0.015 & 0.919 \\
\hline $\begin{array}{l}P \text { for } \\
\text { heterogeneity }\end{array}$ & & 0.369 & & 0.560 & & 0.289 & & 0.035 \\
\hline \multicolumn{9}{|l|}{$\begin{array}{l}\text { rs2298850 } \\
(G>C)\end{array}$} \\
\hline OR $(95 \% \mathrm{CI})^{\mathrm{a}}$ & $\begin{array}{c}0.83 \\
(0.66-1.04)\end{array}$ & $\begin{array}{c}0.95 \\
(0.77-1.18)\end{array}$ & $\begin{array}{c}0.86 \\
(0.65-1.13)\end{array}$ & $0.93(0.78-1.12)$ & $\begin{array}{c}0.85 \\
(0.73-1.00)\end{array}$ & $\begin{array}{c}1.23 \\
(0.66-2.27)\end{array}$ & $\begin{array}{c}0.66 \\
(0.49-0.89)\end{array}$ & $\begin{array}{c}1.01 \\
(0.84-1.21)\end{array}$ \\
\hline$P$ value ${ }^{\mathrm{a}}$ & 0.111 & 0.664 & 0.271 & 0.475 & 0.057 & 0.512 & 0.006 & 0.956 \\
\hline $\begin{array}{l}P \text { for } \\
\text { heterogeneity }\end{array}$ & & 0.398 & & 0.644 & & 0.255 & & 0.019 \\
\hline \multicolumn{9}{|l|}{$\begin{array}{l}\text { rs3755967 } \\
(\mathrm{C}>\mathrm{T})\end{array}$} \\
\hline OR $(95 \% C I)^{\mathrm{a}}$ & $\begin{array}{c}0.82 \\
(0.65-1.03)\end{array}$ & $\begin{array}{c}0.98 \\
(0.79-1.21)\end{array}$ & $\begin{array}{c}0.84 \\
(0.64-1.11)\end{array}$ & $0.95(0.79-1.14)$ & $\begin{array}{c}0.86 \\
(0.73-1.01)\end{array}$ & $\begin{array}{c}1.22 \\
(0.66-2.26)\end{array}$ & $\begin{array}{c}0.67 \\
(0.50-0.91)\end{array}$ & $\begin{array}{c}1.01 \\
(0.84-1.21)\end{array}$ \\
\hline$P$ value $^{\mathrm{a}}$ & 0.09 & 0.841 & 0.226 & 0.559 & 0.069 & 0.532 & 0.009 & 0.932 \\
\hline $\begin{array}{l}P \text { for } \\
\text { heterogeneity }\end{array}$ & & 0.265 & & 0.470 & & 0.284 & & 0.023 \\
\hline
\end{tabular}

${ }^{\mathrm{a}} \mathrm{OR}$ with its $95 \% \mathrm{CI}$ and $P$ value were derived from the additive model (wild-type homozygote vs. heterozygote vs. variant homozygote) using logistic regression adjusted for age, menopausal status, BMI, family history, income, waist circumference, and education.

of developing breast cancer [17]. In addition, the biological active vitamin $\mathrm{D}, 1,25(\mathrm{OH})_{2} \mathrm{D}$, could inhibit breast cancer cell growth by reducing synthesis of estrogen.

Apart from transport function, DBP may also take part in the anticancer process through non-vitamin D-related functions, including roles in chemotaxis and macrophage activation [9]. DBP is thought as a molecule involved in activation macrophages, and it undergoes the deglycosylation process into DBP-macrophage activating factor (DBPMAF) by glucosidases [30]. DBP-MAF may enhance proapoptotic enzymes activity to induce cell apoptosis via the JNK1/2 and p38 pathway, which may inhibit cancer development [31].

In genome-wide association studies, GC rs2282679 was reported to correlate with serum 25(OH)D levels [32]. Furthermore, GC rs2282679 could reduce the cancer risk [33]. SNPs included in our study (rs17467825, rs2298850, and rs3755967) were in high linkage disequilibrium with rs2282679 ( $\mathrm{LD}=1.0,0.9$, and 1.0 , respectively). Our results may support previous reports that GC polymorphism rs2282679 was associated with cancer risk. The rs17467825 polymorphism is $3^{\prime}$-UTR of the GC gene, rs2298850 and rs3755967 located in the intronic region of the GC gene. Though there are fewer researches on the functional effects of GC polymorphisms, potential functions may not exclude that these genetic variants may take part in regulating gene expression or influencing transcription sites to lead to amino acid modification $[34,35]$, and this needs further studies to verify. The changes in the structure of GC proteins may alter biological functions involved in carcinogenesis.

A cohort including 28,965 postmenopausal women found that a larger waist circumference was connected to higher breast cancer risk, especially the risk was elevated 13\% when the waist circumference increased by $10 \mathrm{~cm}$ [36]. We also observed interactive effects between rs2298850, rs3755967 genotypes, and waist circumference on breast cancer risk. These findings suggested that rs2298850 and rs3755967 could modify the susceptibility of breast cancer induced by waist circumference. Gene environment interactions could partly interpret discrepancies in the association between GC gene polymorphisms and breast cancer across different studies. These genetic variants may be worth reevaluating further in other larger studies.

It should be noted that there were several limitations in this study. First, we did not achieve the data about serum $25(\mathrm{OH}) \mathrm{D}$ concentration from the study population, so we could not evaluate the influence of $25(\mathrm{OH}) \mathrm{D}$ concentration on risk of breast cancer among our study population. Second, only the GC gene was evaluated, and we could not 
TABLE 4: Interaction analysis between three SNPs genotypes and waist circumference on breast cancer risk.

\begin{tabular}{|c|c|c|c|c|c|c|}
\hline Genotypes & $\begin{array}{l}\text { Waist circumference } \\
(\mathrm{cm})\end{array}$ & Cases & Controls & $\begin{array}{c}\text { Crude OR }(95 \% \\
\text { CI })\end{array}$ & $\begin{array}{c}\text { Adjusted } \\
\text { OR }(95 \% \mathrm{CI})^{\mathrm{a}}\end{array}$ & $P^{\mathrm{a}}$ \\
\hline \multicolumn{7}{|l|}{ rs17467825 } \\
\hline AA & $\geq 80$ & $\begin{array}{c}283 \\
(35.8 \%)\end{array}$ & $\begin{array}{c}255 \\
(28.1 \%)\end{array}$ & 1.00 & 1.00 & \\
\hline AA & $<80$ & $94(11.9 \%)$ & $\begin{array}{c}147 \\
(16.2 \%)\end{array}$ & $0.58(0.43-0.79)$ & $0.69(0.49-0.98)$ & 0.037 \\
\hline AG & $\geq 80$ & $\begin{array}{c}249 \\
(31.5 \%)\end{array}$ & $\begin{array}{c}259 \\
(28.5 \%)\end{array}$ & $0.86(0.68-1.10)$ & $0.85(0.66-1.09)$ & 0.203 \\
\hline AG & $<80$ & $76(9.6 \%)$ & $\begin{array}{c}155 \\
(17.1 \%)\end{array}$ & $0.44(0.32-0.61)$ & $0.46(0.31-0.66)$ & $<0.001$ \\
\hline GG & $\geq 80$ & $71(9.0 \%)$ & $49(5.4 \%)$ & $1.31(0.87-1.95)$ & $1.22(0.80-1.87)$ & 0.342 \\
\hline GG & $<80$ & $18(2.3 \%)$ & $44(4.8 \%)$ & $0.37(0.21-0.65)$ & $0.40(0.21-0.75)$ & 0.004 \\
\hline $\begin{array}{l}P \text { for multiplicative } \\
\text { interaction }\end{array}$ & & & & & & 0.057 \\
\hline \multicolumn{7}{|l|}{ rs2298850 } \\
\hline GG & $\geq 80$ & $\begin{array}{c}272 \\
(34.1 \%)\end{array}$ & $\begin{array}{c}251 \\
(27.3 \%)\end{array}$ & 1.00 & 1.00 & \\
\hline GG & $<80$ & $95(11.9 \%)$ & $\begin{array}{c}142 \\
(15.4 \%)\end{array}$ & $0.62(0.46-0.85)$ & $0.72(0.51-1.03)$ & 0.069 \\
\hline GC & $\geq 80$ & $\begin{array}{c}264 \\
(33.1 \%)\end{array}$ & $\begin{array}{c}270 \\
(29.3 \%)\end{array}$ & $0.90(0.71-1.14)$ & $0.87(0.67-1.12)$ & 0.280 \\
\hline GC & $<80$ & $77(9.7 \%)$ & $\begin{array}{c}158 \\
(17.2 \%)\end{array}$ & $0.45(0.32-0.62)$ & $0.46(0.32-0.67)$ & $<0.001$ \\
\hline $\mathrm{CC}$ & $\geq 80$ & $71(8.9 \%)$ & $51(5.5 \%)$ & $1.29(0.87-1.92)$ & $1.18(0.77-1.79)$ & 0.443 \\
\hline $\mathrm{CC}$ & $<80$ & $18(2.3 \%)$ & $48(5.2 \%)$ & $0.35(0.20-0.61)$ & $0.37(0.20-0.70)$ & 0.002 \\
\hline $\begin{array}{l}P \text { for multiplicative } \\
\text { interaction }\end{array}$ & & & & & & 0.031 \\
\hline \multicolumn{7}{|l|}{ rs3755967 } \\
\hline $\mathrm{CC}$ & $\geq 80$ & $\begin{array}{c}277 \\
(34.9 \%)\end{array}$ & $\begin{array}{c}252 \\
(27.6 \%)\end{array}$ & 1.00 & 1.00 & \\
\hline $\mathrm{CC}$ & $<80$ & $95(12.0 \%)$ & $\begin{array}{c}144 \\
(15.8 \%)\end{array}$ & $0.61(0.44-0.83)$ & $0.7(0.49-0.99)$ & 0.045 \\
\hline $\mathrm{CT}$ & $\geq 80$ & $\begin{array}{c}257 \\
(32.4 \%)\end{array}$ & $\begin{array}{c}267 \\
(29.2 \%)\end{array}$ & $0.87(0.68-1.11)$ & $0.85(0.66-1.10)$ & 0.222 \\
\hline $\mathrm{CT}$ & $<80$ & $75(9.4 \%)$ & $\begin{array}{c}153 \\
(16.8 \%)\end{array}$ & $0.44(0.32-0.62)$ & $0.46(0.32-0.67)$ & $<0.001$ \\
\hline $\mathrm{TT}$ & $\geq 80$ & $72(9.1 \%)$ & $50(5.5 \%)$ & $1.31(0.88-1.95)$ & $1.21(0.79-1.84)$ & 0.379 \\
\hline TT & $<80$ & $18(2.2 \%)$ & $47(5.1 \%)$ & $0.35(0.20-0.62)$ & $0.37(0.20-0.70)$ & 0.002 \\
\hline $\begin{array}{l}P \text { for multiplicative } \\
\text { interaction }\end{array}$ & & & & & & 0.039 \\
\hline
\end{tabular}

${ }^{a}$ Adjusted by age, menopausal status, BMI, family history, income, and education.

TABle 5: Combined effects on breast cancer risk.

\begin{tabular}{|c|c|c|c|c|}
\hline Number of protective alleles ${ }^{b}$ & $\begin{array}{c}\text { Cases } \\
N(\%)\end{array}$ & $\begin{array}{c}\text { Controls } \\
N(\%) \\
\end{array}$ & OR $(95 \% \mathrm{CI})^{a}$ & $P^{\mathrm{a}}$ \\
\hline 0 & $363(46.30)$ & $390(43.29)$ & 1.00 & \\
\hline $1-2$ & $11(1.40)$ & $12(1.33)$ & $0.90(0.37-2.20)$ & 0.816 \\
\hline $3-6$ & $410(52.30)$ & $499(55.38)$ & $0.81(0.66-0.99)$ & 0.044 \\
\hline$P$ for trend & & & & 0.043 \\
\hline
\end{tabular}

${ }^{a}$ Adjusted by age, menopausal status, BMI, family history, income, waist circumference, and education. ${ }^{\mathrm{b}}$ Combined genotypes were according to protective alleles carried (rs17467825-G, rs2298850-C, and rs3755967-T).

exclude the fact that other genetic variants of vitamin $\mathrm{D}$ pathway genes might also have impacts on risk of breast cancer. Finally, this study was carried out among Chinese women. The associations between breast cancer susceptibility and GC genetic polymorphisms in other ethnic populations require further investigation.

\section{Conclusions}

In summary, our study identified some genetic variants of the GC gene associated with risk of breast cancer in Chinese women. Furthermore, we, for the first time, found that there were potential significant interactions between GC gene 
polymorphisms and waist circumference in susceptibility to breast cancer, thus supporting the insight that genetic variants in conjunction with environmental factors are able to influence individual's cancer risk.

\section{Data Availability}

The data used to support the findings of this study are available from the corresponding author upon reasonable request.

\section{Conflicts of Interest}

The authors declare that there are no conflicts of interest regarding the publication of this paper.

\section{Acknowledgments}

The project of World Cancer Research Fund provided the source of fund (WCRF 2011/RFA/473).

\section{Supplementary Materials}

(1) Supplementary Figure S1: linkage disequilibrium mapping of four SNPs. (2) Supplementary Table S1: basic information of four SNPs in the GC gene. (3) Supplementary Table S2: additive interaction analysis between rs2298850, rs3755967, and rs17467825 genotypes and waist circumference on breast cancer risk. (Supplementary Materials)

\section{References}

[1] F. Bray, J. Ferlay, I. Soerjomataram, R. L. Siegel, L. A. Torre, and A. Jemal, "Global cancer statistics 2018: GLOBOCAN estimates of incidence and mortality worldwide for 36 cancers in 185 countries," CA: A Cancer Journal for Clinicians, vol. 68, no. 6, pp. 394-424, 2018.

[2] W. Chen, K. Sun, R. Zheng et al., "Cancer incidence and mortality in China, 2014," Chinese Journal of Cancer Research, vol. 30, no. 1, pp. 1-12, 2018.

[3] D. Feldman, A. V. Krishnan, S. Swami, E. Giovannucci, and B. J. Feldman, "The role of vitamin D in reducing cancer risk and progression," Nature Reviews Cancer, vol. 14, no. 5, pp. 342-357, 2014.

[4] Y. Kim and Y. Je, "Vitamin D intake, blood 25(OH)D levels, and breast cancer risk or mortality: a meta-analysis," British Journal of Cancer, vol. 110, no. 11, pp. 2772-2784, 2014.

[5] E. Giovannucci, "The epidemiology of vitamin D and cancer incidence and mortality: a review (United States)," Cancer Causes Control, vol. 16, no. 2, pp. 83-95, 2005.

[6] G. Jones, "Extrarenal vitamin D activation and interactions between vitamin $\mathrm{D}(2)$, vitamin $\mathrm{D}(3)$, and vitamin $\mathrm{D}$ analogs," Annual Review of Nutrition, vol. 33, pp. 23-44, 2013.

[7] T. Shao, P. Klein, and M. L. Grossbard, "Vitamin D and breast cancer," Oncologist, vol. 17, no. 1, pp. 36-45, 2012.

[8] M. L. McCullough, R. M. Bostick, and T. L. Mayo, "Vitamin D gene pathway polymorphisms and risk of colorectal, breast, and prostate cancer," Annual Review of Nutrition, vol. 29, pp. 111-132, 2009.

[9] M. Speeckaert, G. Huang, J. R. Delanghe, and Y. E. Taes, "Biological and clinical aspects of the vitamin D binding protein (Gc-globulin) and its polymorphism," Clinica Chimica Acta, vol. 372, no. 1-2, pp. 33-42, 2006.
[10] M. Sinotte, C. Diorio, S. Bérubé, M. Pollak, and J. Brisson, "Genetic polymorphisms of the vitamin D binding protein and plasma concentrations of 25-hydroxyvitamin D in premenopausal women," The American Journal of Clinical Nutrition, vol. 89, no. 2, pp. 634-640, 2009.

[11] H. Maalmi, V. Walter, L. Jansen et al., "Relationship of very low serum 25-hydroxyvitamin D3 levels with long-term survival in a large cohort of colorectal cancer patients from Germany," European Journal of Epidemiology, vol. 32, no. 11, pp. 961-971, 2017.

[12] L. Engelen, C. G. Schalkwijk, S. J. Eussen et al., "Low 25hydroxyvitamin D2 and 25-hydroxyvitamin D3 levels are independently associated with macroalbuminuria, but not with retinopathy and macrovascular disease in type 1 diabetes: the EURODIAB prospective complications study," Cardiovascular Diabetology, vol. 14, p. 67, 2015.

[13] P. Chen, M. Li, X. Gu et al., "Higher blood 25(OH)D level may reduce the breast cancer risk: evidence from a Chinese population based case-control study and meta-analysis of the observational studies," PLoS One, vol. 8, no. 1, Article ID e49312, 2013.

[14] S. Abbas, J. Linseisen, T. Slanger et al., "The Gc2 allele of the vitamin $\mathrm{D}$ binding protein is associated with a decreased postmenopausal breast cancer risk, independent of the vitamin D status," Cancer Epidemiology, Biomarkers and Prevention, vol. 17, no. 6, pp. 1339-1343, 2008.

[15] R. Jorde, H. Schirmer, T. Wilsgaard et al., "The DBP phenotype Gc-1f/Gc-1f is associated with reduced risk of cancer. The Tromsø study," PLoS One, vol. 10, no. 5, Article ID e0126359, 2015.

[16] N. Elkum, F Alkayal, F Noronha et al., "Vitamin D insufficiency in Arabs and South Asians positively associates with polymorphisms in GC and CYP2R1 genes," PLoS One, vol. 9, no. 11, Article ID e113102, 2014.

[17] N. Y. Sofi, M. Jain, U. Kapil et al., "Reproductive factors, nutritional status and serum 25(OH)D levels in women with breast cancer: a case control study," The Journal of Steroid Biochemistry and Molecular Biology, vol. 175, pp. 200-204, 2018.

[18] B. Bade, A. Zdebik, S. Wagenpfeil et al., "Low serum 25hydroxyvitamin D concentrations are associated with increased risk for melanoma and unfavourable prognosis," PLoS One, vol. 9, no. 12, Article ID e112863, 2014.

[19] F. Pibiri, R. A. Kittles, R. S. Sandler et al., "Genetic variation in vitamin D-related genes and risk of colorectal cancer in African Americans," Cancer Causes \& Control, vol. 25, no. 5, pp. 561-570, 2014.

[20] M. J. Knol, T. J. VanderWeele, R. H. H. Groenwold, O. H. Klungel, M. M. Rovers, and D. E. Grobbee, "Estimating measures of interaction on an additive scale for preventive exposures," European Journal of Epidemiology, vol. 26, no. 6, pp. 433-438, 2011.

[21] M. Zheng, J. Liu, M. Zhu et al., "Potentially functional polymorphisms in PAK1 are associated with risk of lung cancer in a Chinese population," Cancer Medicine, vol. 4, no. 11, pp. 1781-1787, 2015.

[22] P. Engel, G. Fagherazzi, A. Boutten et al., "Serum 25(OH) vitamin D and risk of breast cancer: a nested case-control study from the French E3N cohort," Cancer Epidemiology Biomarkers \& Prevention, vol. 19, no. 9, pp. 2341-2350, 2010.

[23] A. V. Krishnan, S. Swami, and D. Feldman, "Vitamin D and breast cancer: inhibition of estrogen synthesis and signaling," The Journal of Steroid Biochemistry and Molecular Biology, vol. 121, no. 1-2, pp. 343-348, 2010. 
[24] M. J. Rowling, C. M. Kemmis, D. A. Taffany, and J. Welsh, "Megalin-mediated endocytosis of vitamin D binding protein correlates with 25-hydroxycholecalciferol actions in human mammary cells," The Journal of Nutrition, vol. 136, no. 11, pp. 2754-2759, 2006.

[25] C. Pilon, R. Urbanet, T. A. Williams et al., " $1 \alpha, 25-$ Dihydroxyvitamin D3 inhibits the human H295R cell proliferation by cell cycle arrest: a model for a protective role of vitamin $\mathrm{D}$ receptor against adrenocortical cancer," The Journal of Steroid Biochemistry and Molecular Biology, vol. 140, pp. 26-33, 2014.

[26] S. Mordan-McCombs, M. Valrance, G. Zinser, M. Tenniswood, and J. Welsh, "Calcium, vitamin D and the vitamin D receptor: impact on prostate and breast cancer in preclinical models," Nutrition Reviews, vol. 65, no. 8 Pt 2, pp. S131-S133, 2007.

[27] C. M. Kemmis, S. M. Salvador, K. M. Smith, and J. Welsh, "Human mammary epithelial cells express CYP27B1 and are growth inhibited by 25-hydroxyvitamin D-3, the major circulating form of vitamin D-3," The Journal of Nutrition, vol. 136, no. 4, pp. 887-892, 2006.

[28] L. Shi, S. Nechuta, Y. T. Gao et al., "Correlates of 25hydroxyvitamin D among Chinese breast cancer patients," PLoS One, vol. 9, no. 1, Article ID e86467, 2014.

[29] B. Shao, S. Jiang, X. Muyiduli et al., "Vitamin D pathway gene polymorphisms influenced vitamin D level among pregnant women," Clinical Nutrition, vol. 37, no. 6 Pt A, pp. 2230-2237, 2017.

[30] N. Yamamoto and R. Kumashiro, "Conversion of vitamin D3 binding protein (group-specific component) to a macrophage activating factor by the stepwise action of beta-galactosidase of B cells and sialidase of T cells," Journal of immunology, vol. 151, no. 5, pp. 2794-2802, 1993.

[31] K. Gumireddy, C. D. Reddy, and N. Swamy, "Mitogen-activated protein kinase pathway mediates DBP-maf-induced apoptosis in RAW 264.7 macrophages," Journal of Cellular Biochemistry, vol. 90, no. 1, pp. 87-96, 2003.

[32] J. Ahn, K. Yu, R. Stolzenberg-Solomon et al., "Genome-wide association study of circulating vitamin D levels," Human Molecular Genetics, vol. 19, no. 13, pp. 2739-2745, 2010.

[33] H. Arem, K. Yu, X. Xiong et al., "Vitamin D metabolic pathway genes and pancreatic cancer risk," PLoS One, vol. 10, no. 3, Article ID e0117574, 2015.

[34] O. Shaul, "How introns enhance gene expression," The International Journal of Biochemistry \& Cell Biology, vol. 91, no. Pt B, pp. 145-155, 2017.

[35] H. I. Nakaya, P. P. Amaral, R. Louro et al., "Genome mapping and expression analyses of human intronic noncoding RNAs reveal tissue-specific patterns and enrichment in genes related to regulation of transcription," Genome Biology, vol. 8, no. 3, p. R43, 2007.

[36] M. M. Gaudet, B. D. Carter, A. V. Patel, L. R. Teras, E. J. Jacobs, and S. M. Gapstur, "Waist circumference, body mass index, and postmenopausal breast cancer incidence in the cancer prevention study-II nutrition cohort," Cancer Causes \& Control, vol. 25, no. 6, pp. 737-745, 2014. 


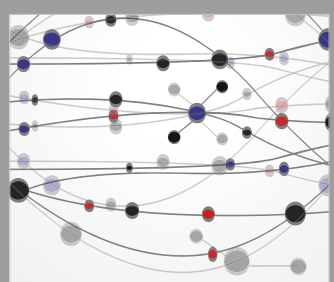

The Scientific World Journal
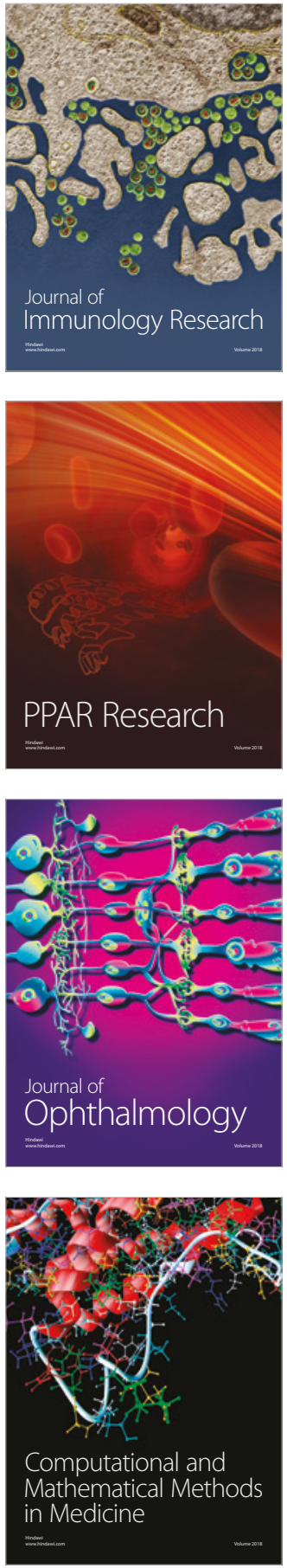

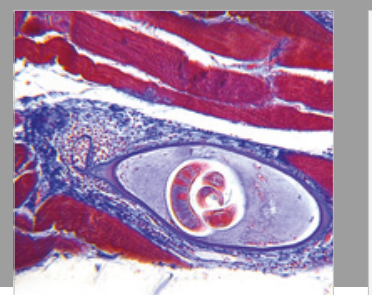

Gastroenterology Research and Practice

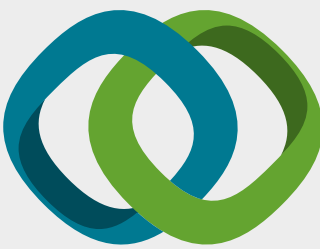

\section{Hindawi}

Submit your manuscripts at

www.hindawi.com
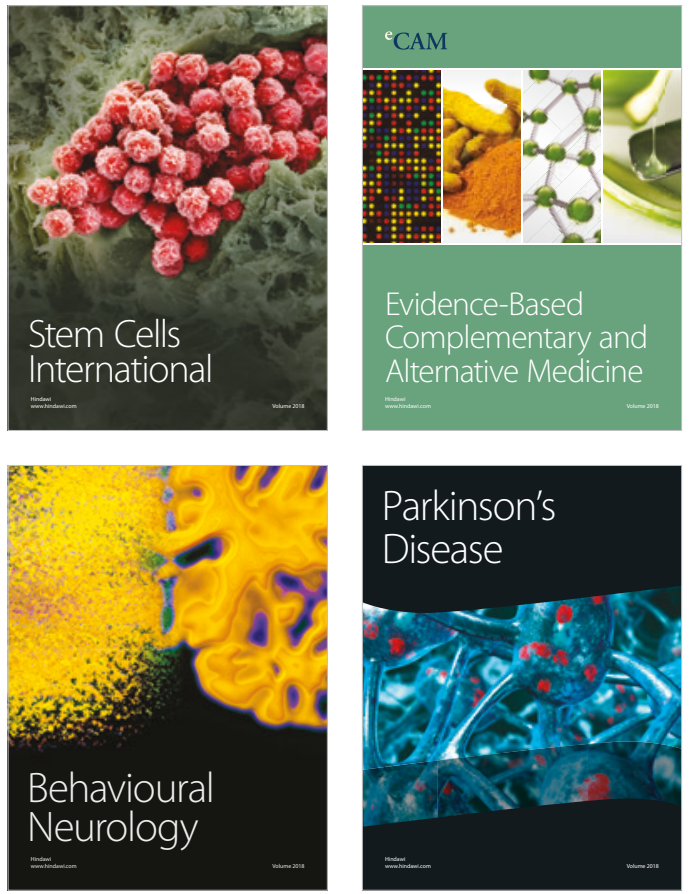

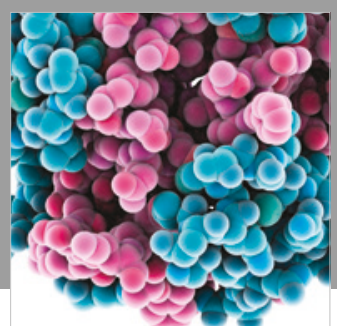

ournal of

Diabetes Research

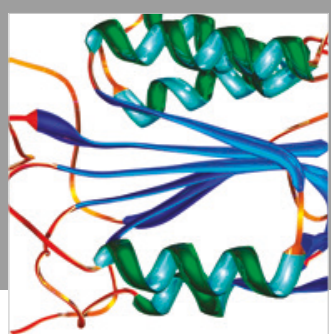

Disease Markers
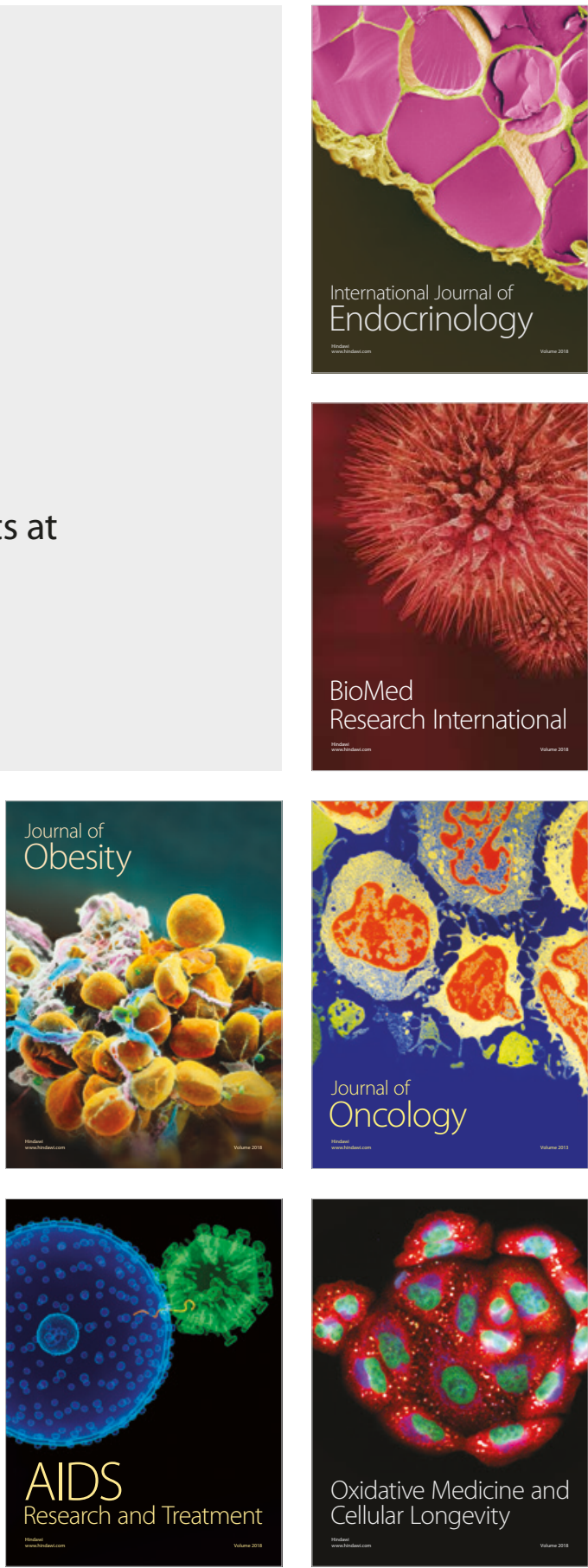